\title{
GCU
}

Glasgow Caledonian

University

University for the Common Good

\section{An exploration of fashion retailer own brand strategies}

McColl, Julie; Moore, Christopher

Published in:

Journal of Fashion Marketing and Management

DOI:

10.1108/13612021111112368

Publication date:

2011

Document Version

Author accepted manuscript

Link to publication in ResearchOnline

Citation for published version (Harvard):

McColl, J \& Moore, C 2011, 'An exploration of fashion retailer own brand strategies', Journal of Fashion

Marketing and Management, vol. 15, no. 1, pp. 91-107. https://doi.org/10.1108/13612021111112368

\section{General rights}

Copyright and moral rights for the publications made accessible in the public portal are retained by the authors and/or other copyright owners and it is a condition of accessing publications that users recognise and abide by the legal requirements associated with these rights.

Take down policy

If you believe that this document breaches copyright please view our takedown policy at https://edshare.gcu.ac.uk/id/eprint/5179 for details of how to contact us. 


\section{An exploration of fashion retailer own brand strategies}

\section{Authors}

Contact:

Dr Julie McColl

Senior Lecturer

Department of Fashion, Marketing and Retailing Glasgow Caledonian University Business School Glasgow

G4 OBA

Email: j.mccoll2@gcal.ac.uk

Professor Christopher Moore

Vice Dean

Glasgow Caledonian University Business School

Glasgow

G4 OBA 


\title{
An exploration of fashion retailer own brand strategies
}

\begin{abstract}
Purpose - It has been proposed within the branding literature that the theory of the brand be extended within a variety of industries. The purpose of this research is to offer a deeper understanding of the centrality of the own brand to fashion retailer brand strategy.
\end{abstract}

Design/methodological approach - The research involved six in depth interviews with large scale fashion retailers from a sample of the twenty largest and most successful fashion retailers in the UK.

Findings - Participants identified the motivations, dimensions, success factors and problems associated with the creation, development and management of the own brand.

Research limitations/implications - This is an exploratory study and as such is limited to the experiences of six fashion retailers. It is, however, part of a larger empirical study.

Practical implications - The results of this study provide key areas for future research development to be applied within the fashion retail sector or to be expanded within alternative retail sectors.

Originality/value - The development of brand strategy within the fashion retailing sector reveals a paucity of empirical and theoretical studies. This exploratory paper seeks to address this scarcity.

Keywords Fashion retailing, branding

Paper type Research paper

\section{Introduction}

Over the past decade, the UK clothing market has suffered from strong deflationary pressures with the influx of, and intense competition from, value retailers such as Primark, New Look and Peacocks who are driving down prices within the market whilst showing consistently strong growth. Many clothing retailers cite this deflation as a key challenge in the present retail climate, in the face of a more demanding, increasingly discerning, and less loyal customer (Keynote 2006; Mintel 2007). Additionally the past two decades have seen a proliferation of foreign retailers entering, and increasing competition within, the UK fashion retail market, with the emergence of companies such as Kookai from France, H\&M from Sweden, Zara and Mango from Spain, Benetton from Italy, and from America, Gap (Keynote 2006). Zara in particular has had a significant impact on UK clothing retailers who have, according to Verdict (2007), been forced to respond to their superior store environments and fast fashion format. In view of increasingly dynamic, complex, and competitive market 
conditions, McGoldrick (2002) proposes that marketing has taken on a pivotal role within the retailing organisation, as the basis for differentiation and positioning, in the establishment of competitive advantage. Recent literature proposes that, critical to this retail marketing activity, is the retailer brand (Davies 1992; 1998; Mitchell 1999; Burt and Sparks 2002; Ailawadi and Keller 2004; Girod 2005; Papasolomou and Vrontis 2006; Martensen 2007) and the fashion retailer brand (Moore 1995; Grime, et al. 2002; Moore and Birtwistle 2005; Hines and Bruce 2007), in serving as a short-hand device for consumer decision making in a decidedly homogenous market (Omar 1999; McGoldrick 2002; Doyle 2004). This literature, however, is underdeveloped and calls have been made for further empirical explorations of retailer brand strategies and the application of traditional branding principles within the retail sector, particularly those of corporate branding and the role of private labels or own brands in the implementation of brand strategy (Ailawadi and Keller 2004).

This study is exploratory and incremental, seeking the elicitation of research questions from the literature, which, through their application within the empirical research, will assist in the identification of the pertinent issues for fashion retailers in the creation, development and management of their brand strategy, and will allow for the creation of a suitable context within which further empirical study can evolve.

\section{Literature review}

\section{Defining the brand}

According to de Chernatony and Dall'Olmo Riley (1998) over the past decade the conceptual focus of the branding literature has experienced evolutionary change whereby brands have been subject to redefinition and redefinement (de Chernatony 2001; Stern 2006; Jevons 2007). Calls have appeared in the literature for a clearer definition of the brand elements which focuses upon the nature, function, locus and valence of the term brand (Brown, et al. 2006; Stern 2006; Jevons 2007), as well as an orderly and consistent terminology which is, according to Stern (2006), essential for scientific enquiry. Recent definitions propose that the brand is the organisation's principal asset and the core business activity (Salzer-Morling and Strannegard 2004) which should be developed on a corporate basis, involving all members of the organisation, particularly in terms of offering employee and stakeholder focus and external coherence and conformity (Ind 1997; Balmer and Grey 2003; Hatch and Schultz 2003; Urde 2003). According to Jevons (2007), however, despite considerable empirical and theoretical research activity, branding remains a fragmented and contextual concept, the 
various characteristics of which have never been captured by a single definition. He defines the brand as:

“... a tangible or intangible concept that uniquely identifies an offering, providing symbolic communication of functionality and differentiation, and in so doing sustainability influences the value offered." (p 6)

Although branding therefore is a clearly established area of research, according to Bridson and Evans (2004) and Blumenthal (2004), it lacks common conceptualisation. According to de Chernatony and Dall'Olmo Riley (1998), there has been a failure within the branding literature to develop the brand construct and boundaries, which would allow for formal, semantical, methodological and epistemological sets of criteria. Accordingly, they carried out a content analysis of over 100 articles from the literature and interviews with key industry brand consultants, and developed a model which they propose lays the foundation for establishing the theory of the brand, thus allowing them to define the brand construct and boundaries. For the analysis, twelve main themes were proposed which categorise the most important propositions in the branding literature, and which therefore helped to set boundaries for the brand construct. These have been updated and are outlined in Table 1 .

de Chernatony and Dall'Olmo Riley (1998) accept that this model is multidimensional, however, emphasis upon each brand construct will vary according to the nature of the company and the brand, and the strategic emphasis placed upon these. They suggest that researchers should test the propositions advanced within this paper amongst brand consultants, managers and consumers, in different areas of industry. 
Table 1. Dimensions of the brand construct

\begin{tabular}{|c|c|c|}
\hline Dimension & Antecedents & Academic contributions \\
\hline $\begin{array}{l}\text { Legal } \\
\text { instrument }\end{array}$ & $\begin{array}{l}\text { Mark of ownership. Name, } \\
\text { logo, design. Trademark }\end{array}$ & $\begin{array}{l}\text { Broadbent and Cooper (1987), } \\
\text { Cranier (1995), Kapfer (2004) }\end{array}$ \\
\hline Logo & $\begin{array}{l}\text { Name, term, sign, symbol, } \\
\text { design. Product } \\
\text { characteristics. }\end{array}$ & $\begin{array}{l}\text { Watkins (1986), Aaker (1991), Dibb, } \\
\text { et al. (1994), Kotler, et al. (1996) }\end{array}$ \\
\hline Company & $\begin{array}{l}\text { Recognisable corporate name } \\
\text { and image. Culture, people, } \\
\text { programmes of organisation } \\
\text { define corporate personality. } \\
\text { CEO is brand manager. }\end{array}$ & $\begin{array}{l}\text { King (1991), de Chernatony (2000), } \\
\text { Balmer and Grey (2003), Hatch and } \\
\text { Schultz (2003), Knox and Bickerton } \\
\text { (2003), Urde (2003) }\end{array}$ \\
\hline Shorthand & $\begin{array}{l}\text { Firm stresses quality not } \\
\text { quantity of information. }\end{array}$ & $\begin{array}{l}\text { Jacoby, et al. (1977), Brown (1992), } \\
\text { Chevan (1992), Sheth, et al. (1999) }\end{array}$ \\
\hline Risk reducer & $\begin{array}{l}\text { Confidence that expectations } \\
\text { being fulfilled. }\end{array}$ & $\begin{array}{l}\text { Staveley (1987), Assael (1998), } \\
\text { Keller (1998), Doyle (2004), Kapfer } \\
(2004)\end{array}$ \\
\hline $\begin{array}{l}\text { Identity } \\
\text { system }\end{array}$ & $\begin{array}{l}\text { More than just a name. } \\
\text { Holistic, structured with six } \\
\text { integrated facets, including } \\
\text { brand personality. }\end{array}$ & $\begin{array}{l}\text { Doyle (1990), Fombrun and Shanley } \\
\text { (1990), Diefenbach (1992), Dibb, et } \\
\text { al. (1994), Aaker (1996), Balmer and } \\
\text { Grey (2003), Keller (2003), Kapfer } \\
\text { (2004), Kotler and Keller (2006) }\end{array}$ \\
\hline Image & $\begin{array}{l}\text { Consumer centred. Image in } \\
\text { consumer's mind is brand } \\
\text { reality. }\end{array}$ & $\begin{array}{l}\text { Gardner and Levy (1955), Boulding } \\
\text { (1956), Martineau (1958), Park, et al. } \\
\text { (1986), Keeble (1991), Arnold } \\
\text { (1992), Keller (1998), Kapfer (2004) }\end{array}$ \\
\hline Value system & $\begin{array}{l}\text { Consumer relevant values } \\
\text { imbue the brand. }\end{array}$ & $\begin{array}{l}\text { Doyle (1990), Sheth, et al. (1991), } \\
\text { Cook (1995), Meeghan (1995), } \\
\text { Balmer (2001), Urde (2003) }\end{array}$ \\
\hline Personality & $\begin{array}{l}\text { Psychological values, } \\
\text { communicated through } \\
\text { advertising and packaging } \\
\text { define the brand personality. }\end{array}$ & $\begin{array}{l}\text { Hirschman and Holbrook (1982), } \\
\text { Plummer (1985), Park, et al. (1986), } \\
\text { Belk (1988), Aaker (1996), Keller } \\
\text { (1998) }\end{array}$ \\
\hline Relationship & $\begin{array}{l}\text { Consumer has attitude to } \\
\text { brand. Brand as a person has } \\
\text { attitude to consumer. }\end{array}$ & $\begin{array}{l}\text { Duboff (1986), Arnold (1992), } \\
\text { Blackston (1992), Woodard, et al. } \\
\text { (1994), Rubenstein (2002), Kapfer } \\
\text { (2004) }\end{array}$ \\
\hline Adding value & $\begin{array}{l}\text { Non-functional extras. Value } \\
\text { satisfier. Consumers imbue } \\
\text { brand with subjective } \\
\text { meaning they value enough to } \\
\text { buy. Aesthetics. Enhanced } \\
\text { through design, manufacturer, } \\
\text { distribution. }\end{array}$ & $\begin{array}{l}\text { King (1973), Hirschman and } \\
\text { Holbrook (1982), Jones (1986), de } \\
\text { Chernatony (2000) }\end{array}$ \\
\hline $\begin{array}{l}\text { Evolving } \\
\text { entity }\end{array}$ & $\begin{array}{l}\text { Change by stage of } \\
\text { development. }\end{array}$ & Goodyear (1996) \\
\hline
\end{tabular}

Source: updated and adapted from de Chernatony and Dall'Olmo Riley (1998) 
This model helps provide epistemological criteria for the analysis of the fashion retailer brand.

\section{From product brand to corporate brand}

The dominant theme of the early branding literature was concerned with the strategic goals of management, focusing upon the creation of differentiation, adding values through the tangible features of the product brand (Farquhar 1990) using trademarks, logos, and the promotion of the functional benefits of the brand (Copeland 1923; Gardner and Levy 1955; Kotler 1984; Jones 1986; Kotler, et al. 1996). According to Harris and de Chernatony (2001), there has been a shift in the brand literature from brand management which is consumer focused, to brand identity which focuses on how managers and employees make a brand unique. Additionally, a move towards globalisation, such as that which has occurred in fashion retailing (Moore 1998; Moore 2000; Moore and Birtwistle 2004) has led to a shift in emphasis from product brands to corporate brands as a communicator of corporate ideology and image (Aaker 1996; Ind 1997; de Chernatony 1999; Aaker and Joachimstaler 2000; Knox, et al. 2000; Olins 2000; Balmer 2001; Harris and de Chernatony 2001; Hatch and Schultz 2003; Kapfer 2004). It has been suggested that the development and implementation of own brand strategy is a vital element of retailer corporate strategy (Moore 1995; Burt 2000; Martensen 2007), the range and type of own brands developed being directly related to the corporate brand image (Ailawadi and Keller 2004). These own brands offer retailers control of growth strategies, strengthen retailer positioning and offer opportunities for developing market power (Davies 1992; McGoldrick 2002; Sheinin and Wagner 2003).

\section{The development of own brand strategy}

Veloutsou, et al. (2004) propose that there is no universally accepted terminology used in the classification of retailer brands, citing from the literature five definitions, own label products/brands, private label products/brands, retailer products/brands, distributors brands and store brands or labels. The term generally used in the USA is private label (Diamond 2006), however, it has been suggested in the UK literature that own brand is the most accurate term (de Chernatony 1989; Burt and Davis 1999; McGoldrick 2002). This therefore is the term which is used throughout this study. These definitions are drawn from the generic retailing literature, and no such classification exists within the fashion retailing literature. 
According to Martensen (2007), a coherent identity that reflects the values of the corporate brand has a positive impact on store brands carrying the corporate brand name. Burt (2000) cites Morris (1979) as a base definition of the retailer own brand. He proposes that retailer own brands are:

"... consumer products produced by or on behalf of distributors and sold under the distributers own name or trademark through the distributors own outlet." (p 875)

Burt and Sparks (2002) suggest that successful retailers have developed their own brand strategies from first generation generics to highly sophisticated extensions of the corporate brand in terms of image and values.

An important feature of British fashion retailing is the extent to which leading fashion retailers either exclusively or predominantly sell products marketed under their own name (Tungate 2005; Keynote 2007). Many of the UK's leading fashion retailers have developed strong own brands which serve to encapsulate and communicate their market position relative to their competitors (Jones and Rigby 2005; Tungate 2005; Verdict 2007). Fernie et al (2003) and Moore (1995) suggest that the fashion retailer own brand is the primary focus for resource investment and a significant business asset. It has been suggested that the importance of own brands has increased dramatically in recent years, particularly in portraying the corporate brand image (Burt and Sparks 2002), contributing to store differentiation (Sudhir and Talukdar 2004), allowing for control over merchandise design (Juhl, et al. 2006), packaging (Wells, et al. 2007), pricing (Carpenter, et al. 2005), quality and store image (Berman and Evans 2004) and inventory control (Juhl, et al. 2006). Although a few studies specifically consider the motivations for own brand development within the retailing sector, no study has considered the motivations specific to own brand development within fashion retailing. The first research question is therefore associated with motivations for fashion retailer own brand development.

There is no clear delineation of the dimensions of the own brand within the generic branding literature, however, issues such as quality, price, differentiation and brand image are apparent within the literature (de Chernatony and Dall'Olmo Riley 1998; Bridson and Evans 2004; McGoldrick 2002). Within the fashion retailing sector, a small number of studies have sought to identify the utilitarian and symbolic dimensions of the fashion retailer own brand, those of design, brand personality, economies of scale in production, supply chain control, 
brand positioning and design (Moore 1995; Vahie and Paswan 2006), and similarly those of the luxury fashion brand (Moore and Birtwistle 2005; Hines and Bruce 2007). However, only a small number of such studies exist, particularly within the fashion retailing sector. The second research question therefore is associated with the essential components of the fashion retailer own brand.

According to the literature, the success of the own brand is reflected within the values and success of the corporate brand (Ailawadi and Harlem 2004; Juhl, et al. 2006) and unique and differentiated products (Burt and Sparks 2002). Others have identified the importance of a coherent corporate and own brand image and store design congruency (Porter and Claycomb 1997; Vahie and Paswan 2006; Kent 2003; 2007), a small number of these studies being within the fashion retailing sector (Birtwistle and Freathy 1998; Carpenter, et al. 2005). However, few studies exist within the fashion retailing sector which seek to define clearly the factors critical to the success of the fashion retailer own brand. The third research question therefore is associated with factors critical to the success of the British fashion retailer own brand development.

A small number of studies have emerged which highlight the disadvantages of own brand development within the retail sector, the main issues being those of negative perceptions of the corporate brand generated through incongruent customer perceptions, poor own brand quality or own brand failures, price sensitivity and the damage that these can do to store image (Richardson, et al. 1996; Baltas and Argouslidis 2007). No studies, as such, identify the problems associated with own brand development within the fashion retailing sector, although a small number of issues have been identified within the literature, those of incongruency between merchandise and store image, lack of differentiation within the market and indiscriminate licensing agreements (Moore and Birtwistle 2004; Sheinin and Wagner 2003). The fourth research question is therefore associated with the problems/challenges for British fashion retailers in the development and management of the own brand.

The questions provided below therefore are drawn from the literature review and serve primarily to provide direction for the research study and a structure for the research findings:

1. What are the motivations for fashion retailer own brand development?

2. What are the essential components of the fashion retailer own brand? 
3. What are the factors critical to the success of the fashion retailer own brand development?

4. What are the problems/challenges for fashion retailers in the development and management of the own brand?

\section{Methodology}

de Chernatony and Dall'Olmo Riley (1998) have provided the construct and boundaries of the brand which they recommend be extended within other industry sectors. Accordingly, their research has helped provide a theoretical basis for this analysis of the fashion retailer own brand. The decision to focus on large scale companies is supported by evidence provided in previous studies (Ambler and Styles 1997; de Chernatony 1999; Harris and de Chernatony 2001; Einwiller and Will 2002; Hatch and Schultz 2003; Moore and Birtwistle 2004; Moore and Birtwistle 2005), that large scale companies offer examples of dominant management practices and complexity of operations in terms of supply chain ownership and management. According to Retail Knowledge Bank (www.retailknowledgebank.net 2004), $85 \%$ of UK retail sales come from only 500 companies which therefore enjoy significant market share and exhibit extensive market coverage. These 500 companies have been compiled by the Retail Knowledge Bank into a list for the trade magazine Retail Week, called Retail Week 500. Participant companies therefore were identified and selected on the following criteria. To be selected, the fashion retailers must be included in the Retail Week top 500, have been in business for at least five years to ensure high levels of experience, to sell own brands and, again for reasons of experience, have sold own brands for at least two years. This list was considered to be the most up to date data base of large scale retailers and was used to identify 139 fashion retailers. Given these characteristics, it was felt that the potential participants would provide credible information as to the creation and management of brand strategy within the fashion retail sector. This research is part of a wider research project, however, for the purposes of this study, a letter was sent to the top 20 fashion retailers in terms of scale and turnover, from the population sample of 139 and six responded. Of this sample two were general fashion retailers described by Mintel (1998) as offering a broad range of fashion merchandise and accessories to mass market customers (Corporate Intelligence on Retailing 1997). Two were specialist fashion retailers serving a clearly defined target customer, one designer fashion retailer, selling merchandise through outlets bearing the designer's name, or associated name, and one specialist footwear retailer focusing upon a narrow and specific product range (Corporate Intelligence on Retailing 1997). The final two were general merchandise retailers identified by Mintel (1998) as retailers located in 
key shopping centres who include a mix of fashion and non-fashion goods within their merchandise offer. This provided a broad range of fashion retailers, proposed by Moore (2000) to be representative of the fashion retailing sector. The interviewees were asked open ended questions about the development and management of the own brand, based upon the research questions developed. All interviewees requested confidentiality. The interviews were carried out with senior management personnel (marketing and brand directors/managers) who, it was ensured, had direct experience in the areas of own brand portfolio management, buying, or merchandise management. The interviews were approximately two hours long, took place in the company head office, and were transcribed and analysed using the NUDIST qualitative analysis package.

Index trees within the NUD*IST software package allowed the comparison, identification, retrieval and exploration of issues and concepts relevant to the participants.

\section{Results and discussion.}

In accordance with the research questions outlined above, interviewees were asked about their motivations for developing own brands. In general, respondents felt that the development of own brands offered a number of distinct advantages. The main one was the issue of control. The development of own brands allowed them control over the implementation of their corporate brand strategy and operations in terms of cost control, pricing, quality, differentiation, design and merchandising, and therefore, overall positioning of the own brand within the market. Additionally, it allowed them to extend the brand into new markets, particularly for one respondent, offering licensing or franchising opportunities. One general fashion retailer, who also sold manufacturer brands, explained:

With the manufacturer brands we try to get different stock from competing stores. With own brands, it is easy. No one else sells these in the city centre. We also find it easier to avoid stock outs with own brands, and are more in control of our own merchandising. Sometimes, manufacturers want some control over how and where their merchandise is displayed.

The motivations for developing an own brand strategy therefore were issues concerned with strategic positioning, expansion, and control over supply chain and store operations.

Interviewees were then asked what they thought were the essential components of the own brand. For five of the six interviewees, the most important component was the corporate brand itself, its trade mark or logo, image, philosophy and reputation. Supported by the work of Davies (1992) and Moore (1995), four of these interviewees stressed the importance of 
being able to use the corporate brand name on own brands as being a way of transferring the values associated with the corporate brand over to the merchandise. One saw no point in using a different name as this lost some of the identity which had been built up over the years, however, another said that they had used a different name on their sportswear as they felt that the corporate brand name did not have a "sporty" image. The brand manager of the designer fashion company stressed the importance of design and creativity within the merchandise. He explained:

For our company, design is the most important element of our brand strategy. Own brands allow us to be radical and experimental and customers recognised us for this. We recently held a competition for new designers, using a number of the winning designs within our collection.

This is what he felt the company represented. The respondents stressed the importance of own brand dimensions as a means of managing the overall company brand strategy, and two stated that the own brand dimensions were possibly the most important issues to the brand and image management process.

The components that respondents felt to be essential to own brands, therefore, were the influence of corporate brand image and reputation, design and creativity. Respondents stressed the importance of these dimensions to the management of the brand strategy.

Respondents identified a range of critical success factors for own brands reporting that own brands could be exclusive to the company and could focus on the needs of the target market. Other issues were those of control over and consistency of brand image not only within the store but also in terms of merchandise and communication. One general fashion retailer explained that, because of their in-house design team and their control of the supply chain, they were able to ensure that cat walk styles were in their shop within weeks and the delivery of styles was consistent with the existing brand image. The footwear retailer stressed the need for trained staff, particularly in his case, where some expertise about the product was needed.

A few participants identified a recent increase in advertising and personality endorsement within fashion retailing as a means of increasing market share. Reaction to this development was mixed. One general fashion retailer reported that they did not do any advertising, their high street presence and in-store photography were their advertising. The retailer also 
produced a catalogue, which acted as a form of advertising. The remaining interviewees advertised in magazines and felt that this was important to the own brand, but, as one interview responded, it could be damaging if the merchandise is not in the shop because the advertising had increased awareness and demand. It could, however, be difficult to assess the increase in demand. One general merchandise retailer had recently begun a television advertising campaign which had been highly successful in boosting sales. Reaction to personality endorsement was mixed. One general fashion retailer had tried it and found it to be successful, but stated that the personality used must be closely matched to the brand personality. They had found it to be very expensive and only carried out campaigns, such as this, intermittently. The designer retailer did not use personalities but occasionally gave merchandise to personalities to wear. This had been very successful in terms of the endorsement of the brand as the personalities who wore the brand were considered to be "cool".

One general merchandise retailer was currently using personalities very successfully to target a number of different market segments. The remaining fashion retailers did not use personality endorsement. One felt that the use of young models in the portrayal of the own brand personality, whose image matched that of the target customer, was sufficient.

The main issues associated with the success of the own brand were felt to be consistency over design and delivery of the own brand image and merchandise particularly in terms of store image, advertising, celebrity endorsement, and trained staff.

Finally, respondents were asked about any problems which might be associated with the development and management of the own brand. Interviewees had experienced varying problems when managing the own brand, and two were particularly concerned about the impact of increased competition and price deflation on profit margins. One general fashion retailer explained that although they controlled the distribution of merchandise, they were supplied by a number of manufacturers, some of whom they had more control over than others. Inconsistency in quality and delivery could be damaging to the reputation of the company. He proposed:

In the past, we experienced problems with a small number of suppliers not delivering merchandise on time. We had also occasionally had problems with product quality. In these cases, we ceased to use the supplier, however, this creates the problem of finding new suppliers at short notice. 
Issues of quality and inability to supply customers with "fast fashion" could be damaging to the brand. One specialist fashion retailer had experienced problems with goods sold under licence. Again, these were of poor quality, and were, as far as he was concerned, damaging to the corporate brand reputation.

Issues connected with store management were more difficult for interviewees to assess, however feedback from store managers indicated that on a few occasions, merchandise was not really suitable for the target market. One general merchandise retailer explained that occasionally goods were delivered to the store that the staff called "dogs" which were unsuitable in either style or material. In this case, staff felt that they could have predicted this, at a local level, better than the buyers. Additional problems at store level were with allocation and distribution, visual merchandising and in some cases, high staff turnover which could lead to poorer levels of customer service. One general fashion retailer explained that there were occasions where, during advertising campaigns, stock sold out rapidly and they were unable to replenish it quickly enough to meet customer demand. On another occasion, merchandise had been advertised in a fashion magazine, but was not available in the store on time.

In terms of visual merchandising, one general merchandise retailer said that staff had complained that they were asked to stick rigidly to store plans, which they felt were unsuitable to their local customers. One area, for example, had an ageing population whose tastes were quite different to some of the merchandise which had been given prominence. There had been other occasions where the climate was quite different and summer ranges were not suitable throughout the country. More recently, they had attempted to give store managers and local visual merchandisers a little more decision making power, this, however, could affect the consistency of the brand delivery.

The main problems that respondents had experienced, therefore, were control over manufacturers in terms of quality and delivery, and problems at store level with suitability, allocation and distribution of merchandise, visual merchandising and staff turnover which could impact on customer service. 


\section{Conclusion}

The results of this research suggest that the own brand is a strategic tool for fashion retailers in the portrayal and control of the corporate brand within the market. The issues associated with own brand creation, development and management for fashion retailers resulting from the findings of the research are highlighted in Table 2. The motives for own brand creation highlighted within the table are clearly those of control, competitive advantage and ultimately profit. Own brands differentiate fashion retailers in a highly competitive market and were acknowledged to be the means by which fashion retailers could, in operational terms, control not only the supply chain, but also the portrayal of the brand through advertising, design, merchandise and store image offering opportunities for expansion. This level of control allows fashion retailers to react more quickly to market developments.

Table 2. Important issues in the creation, development and management of the fashion retailer own brand

\begin{tabular}{|c|c|}
\hline $\begin{array}{l}\text { MOTIVES } \\
\text { Proactive: } \\
\text { strengthens corporate brand } \\
\text { capitalises on the existence of strong brand name } \\
\text { offers higher gross margins } \\
\text { gives focus for investment } \\
\text { offers control over product range } \\
\text { offers control over pricing } \\
\text { offers control over selling environment } \\
\text { gives control of product designs, } \\
\text { allows for exclusivity, } \\
\text { allows for differentiation of product, } \\
\text { allows for product innovation } \\
\text { provides control over quality standards } \\
\text { Reactive: } \\
\text { to protect from competitor attack } \\
\text { Facilitating: } \\
\text { reinforces of market positioning } \\
\text { provides the ability to remain competitive } \\
\text { allows for expansion of product lines } \\
\text { proffers the ability to offer franchise agreements } \\
\text { proffers the ability to offer licence agreements } \\
\text { offers sales growth in new markets }\end{array}$ & $\begin{array}{l}\text { STRATEGIC COMPONENTS } \\
\text { Brand identity specific: } \\
\text { significance of corporate brand reputation } \\
\text { use of corporate brand logo or trademark } \\
\text { use of corporate brand name as own brand name } \\
\text { use of different own brand name } \\
\text { repetition of corporate image } \\
\text { communications } \\
\text { influence of corporate philosophy } \\
\text { psychological value to the customer } \\
\text { Product specific: } \\
\text { own brands for different segments } \\
\text { creative direction } \\
\text { Store specific: } \\
\text { trading format }\end{array}$ \\
\hline $\begin{array}{l}\text { CRITICAL SUCCESS FACTORS } \\
\text { Corporate brand interface: } \\
\text { consistent own brand delivery } \\
\text { focused market position } \\
\text { market research } \\
\text { brand personality } \\
\text { distribution partnerships } \\
\text { buying power } \\
\text { quick response capability } \\
\text { Product interface: } \\
\text { trends forecasting } \\
\text { exclusivity } \\
\text { quality } \\
\text { brand portfolio } \\
\text { in house design capability } \\
\text { control over supply chain }\end{array}$ & 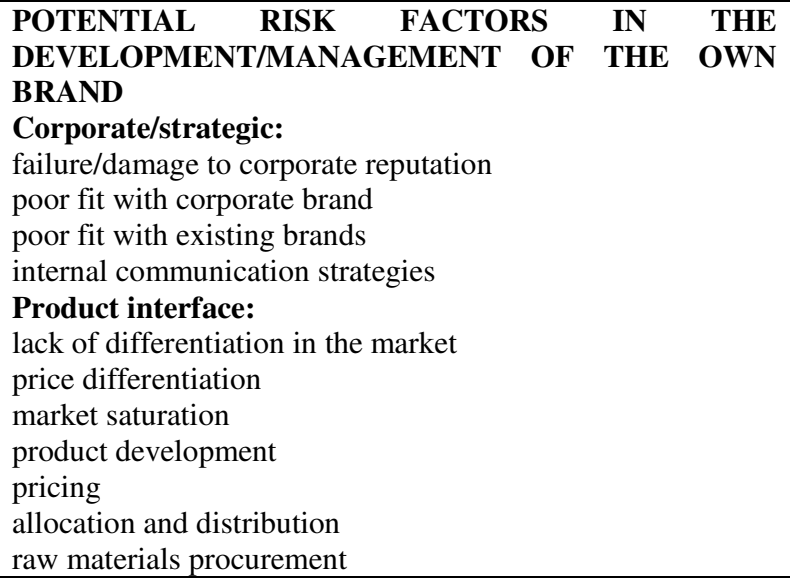 \\
\hline
\end{tabular}


External Communication:

personality endorsement

marketing communications

packaging

Store Communication:

control of own brand image

Customer interface:

customer service

staff training

caliber of staff consistent delivery

supply chain control

External Communication:

marketing communications

Store Communication:

visual merchandising

retail format

store design

Customer interface:

staff and management issues

customer service

staff training

staff development

In strategic terms, the own brand can capitalise on the strength of the corporate brand, and importantly, is central to the delivery of the corporate brand image and operations to the market. Ultimately, however, the creation, development and management of the own brand is complex, and the intricacies of the process impact upon the representation of the corporate brand within the public domain. The management of the own brand is subject to a certain degree of risk in terms of delivery to the market. Participants were aware of the problems involved in the control of large scale operation and worked to minimise this risk through the instigation of centralised control of company policy whilst allowing a degree of flexibility in terms of local management in order to respond to local customer needs.

This study builds upon the work of de Chernatony and Dall'Olmo Riley (1998), extending their research within the fashion retailing sector, delineating the issues associated with the creation, development and management of the fashion retailer own brand. The results of this research, outlined in Table 2, help provide an understanding of the issues of greatest importance to fashion retailers in presenting their own brand strategy to the market and create insights into the management practices which contribute to its success. The clear indication for fashion retailers is the need to understand the importance of the own brand as both a strategic and marketing tool, which requires centralised control of operational management to ensure consistency of brand image in terms of external brand communications and internal store environments, and necessitates centralised staff policies to ensure consistency and excellence in terms of customer interface.

Further investigations which highlight the relative importance to fashion retailers of each of the issues emphasised within this paper and their impact upon the holistic process involved in the creation, development and management of fashion retailer brand strategy is required. Moreover, we do not understand the importance of these issues upon the potential purchase 
behaviour of the consumer, vital within an industry where service contact is fundamental to the exchange relationship. This study has the potential to be replicated within other sectors of the retailing industry thus extending current knowledge of retailer brand strategies. 


\section{References}

Aaker, D. (1996). Building Strong Brands. New York, Free Press.

Aaker, D. (1991). Managing Brand Equity: Capitalising on the Value of a Brand Name. New York, Free Press.

Aaker, D. and E. Joachimstaler (2000). "The brand management relationship spectrum: the key to the brand architecture challenge." Calafornia Management Review 42(4): 8-23.

Ailawadi, K. L. and B. Harlam (2004). "An empirical analysis of the determinants of retail margins: the role of store-brand market share." Journal of Marketing 68(January): 147-165.

Ailawadi, K. L. and K. L. Keller (2004). "Understanding retail branding: conceptual insights and research priorities." Journal of Retailing 80: 331-342.

Ambler, T. and C. Styles (1997). "Brand development versus new product development: towards a process model of extension decisions." Journal of Product and Brand Management 6(1): $13-26$.

Arnold, D. (1992). The Handbook of Brand Management. US, Century Business: The Economist Books.

Assael, H. (1998). Consumer Behavior and Marketing Action. Cincinnati, Ohio, SouthWestern College Publishing.

Balmer, J. M. T. and E. R. Grey (2003). "Corporate brands: what are they? What of them?" European Journal of Marketing 37(7/8): 972-997.

Balmer, J. M. T. (2001). "Corporate identity, corporate branding and corporate branding. Seeing through the fog." European Journal of Marketing 35(3/4): 248-291.

Baltas, G. and P. C. Argouslidis (2007). "Consumer characteristics and demand for store brands." International Journal of Retail and Distribution Management 35(5): 328-341.

Belk, R. W. (1988). "Posessions and the extended self." Journal of Consumer Research 19(December): 339-361.

Berman, B. and J. Evans (2004). Retail Management: A Strategic Approach. Upper Saddle River, NJ, Prentice-Hall.

Birtwistle, G. and P. Freathy (1998). "More than just a name above the shop: a comparison of the branding strategies of two UK fashion retailers." International Journal of Retail and Distribution Management 26(8): 318-323.

Blackston, M. (1992). "Observations: building brand equity by managing the brand's relationships." Journal of Advertising Research 32(May/June): 79-83.

Blumenthal, D. (2004). "For the end ofbrand balderdash - and the beginning of the real future." Brand Management 11(3): 177-179. 
Bridson, K. and J. Evans (2004). "The secret to a fashion advantage is brand orientation." International Journal of Retail \& Distribution Management 32(8): 403-411.

Broadbent, K. and P. Cooper (1987). "Research is good for you." Marketing Intelligence and Planning 5(1): 3-9.

Brown, G. (1992). People, Brands and Advertising. Warwick, Millward Brown International.

Brown, T., P. A. Dacin, et al. (2006). "identity, intended image, constructed image and reputation: an interdisciplinary framework." Journal of the Academy of Marketing Science 34(2): 99-106.

Boulding, K. E. (1956). The Image. Ann Harbour, University of Michigan.

Burt, S. (2000). "The strategic role of retail brands in British grocery retailing." European Journal of Marketing 34(8): 875-890.

Burt, S. and L. Sparks (2002). "Corporate branding, retailing and retail internationalisation." Corporate Reputation Review 194-212.

Burt, S. and S. Davis (1999). "Follow my leader? Lookaloke retailer brands in nonmanufacturer-dominated product markets in the UK." The International Review of Retail, Distribution and Consumer Research 9(2): 163-185.

Carpenter, J. M., M. Moore, et al. (2005). "Consumer shopping for retail brands." Journal of Fashion Marketing and Management 9(1): 43-53.

Chevan, H. (1992). "What's in a Name?" Catalogue Age 9(9): 28.

Cook, W. A. (1995). "You don't have to be schizophrenic." Journal of Advertising Research 35(1): 5-6.

Copeland, M. (1923). "Relation of consumer's buying habits to marketing methods." Harvard Business Review 1(April): 282-289.

Corporate Intelligence on Retailing. (1997). Clothing Retailing in Europe. The Corporate Intelligence Group. London.

Cranier, S. (1995). The Real Power of brands: Making Brands Work for Competitive Advantage. London, Pitman Publishing.

Davies, G. (1992). "The two ways in which retailers can be brands." International Journal of Retail \& Distribution Management 20(2): 24-34.

Davies, G. (1998). "Retailer brands and the theft of identity." International journal of Retail and distribution management 26(4): 140-146.

Diamond, E. (2006) Fashion Retailing a Multi Channel Approach, $2^{\text {nd }}$ ed, New Jersey, Prentice Hall. 
de Chernatony, L. (2001). "Would a brand smell any sweeter by a corporate name?" Corporate Reputation Review 5(2-3).

de Chernatony, L. (2000). "Added values: it's nature, roles and sustainability." European Journal of Marketing 43(1/2): 39-56.

de Chernatony, L. (1999). "Brand management through narrowing the gap between brand identity and brand reputation." Journal of Marketing Management 15: 157-179.

de Chernatony, L. and F. Dall'Olmo Riley (1998). "Defining a brand: beyond the literature with experts interpretations." Journal of Marketing Management 14: 417-443.

de Chernatony, L. (1989). "Branding in an era of retailer dominance." International Journal of Advertising 8: $245-260$.

Dibb, S., L. Simkin, et al. (1994). Marketing. Boston, Houghton Mifflin. Kapfer, J. N. (2004). Strategic Brand Management. London, Kogan Page.

Diefenbach, J. (1992). The Corporate Identity as the Brand. Branding: A Key Marketing Tool. J. M. Murphy. Basingstoke, Macmillan: 156-164.

Doyle, P. (2004). Value Based Marketing. Chichester, John Wiley \& Sons Ltd.

Doyle, P. (1990). "Building Successful Brands: Strategic Options." The Journal of Consumer Marketing Vol 7(No 2): pp 5-20.

Duboff, R. S. (1986). "Brands, like people, have personalities." Marketing News 20(1): 8.

Einwiller, S. and M. Will (2002). "Towards an integrated approach to corporate branding-an empirical study." Corporate Communications. An International Journal 7(2): 100-109.

Farquhar, P. H. (1990). "Managing Brand Equity." Journal of Advertising Research 30(4): 17.

Fernie, J., S. Fernie, et al. (2003). Principles of Retailing. Oxford, Butterworth and Heineman.

Fombrun, C. and M. Shanley (1990). "What's in a name? Reputation building and corporate strategy." Academy of Management Journal 33(2): 233-258.

Gardner, B. B. and S. J. Levy (1955). "The product and the brand." $\underline{\text { Harvard Business Review }}$ 33(March-April): 33-9.

Girod, S. J. G. (2005). "The human resource management practice of retail branding." International Journal of Retail and Distribution Management 33(6/7): 514-530.

Goodyear, M. (1996). "Divided by a common language: diversity and deception in the world of global marketing." Journal of the Market Research Society 38(2): 105-122. 
Grime, I., A. Diamantopoulos, et al. (2002). "Consumer evaluations of extensions and their effects on the core brand. Key issues and research propositions." European Journal of Marketing 36(11/12): 1415-1438.

Harris, F. and L. de Chernatony (2001). "Corporate branding and corporate brand performance." European Journal of Marketing 35(3/4): 441-456.

Hatch, M. J. and M. Schultz (2003). "Bringing the corporation into corporate branding." European Journal of Marketing 37(7/8): 1041-1064.

Hines, T. and M. Bruce (2007). Fashion Marketing - Contemporary Issues. London, Butterworth Heinemann.

Hirschman, E. C. and M. B. Holbrook (1982). "Hedonic Consumption: Emerging Concepts, Methods, and Propositions." Journal of Marketing 46(Summer): 92-101.

Ind, N. (1997). The Corporate Brand. London, Macmillan.

Jacoby, J., G. J. Szybillo, et al. (1977). "Information acquisition behaviour in brand choice situations." Journal of Consumer Research 3: 209-216.

Jevons, C. (2007). Towards an integrated definition of a brand. Thought Leaders International Conference on Brand Management, Birmingham.

Jones, A. and E. Rigby (2005). A good fit? Designers and mass-market chains try to stitch their fortunes together. Financial Times. London: 17.

Jones, J. P. (1986). What's in a Name? D.C. Heath, Lexington, Gower Hampshire.

Juhl, H. J., L. Esbjerg, et al. (2006). "The fight between store brands and national brands: what's the score." Journal of Retailing and Consumer Services(13): 331-338.

Kapfer, J. N. (2004). Strategic Brand Management. London, Kogan Page.

Keeble, G. (1991). Creativity and the Brand. Understanding Brands by 10 People Who Do. D. Cowley. London, Kogan Page: 167-182.

Keller, K. L. (2003). "Understanding brands, branding and brand equity." Interactive Marketing 5(1): 7-20.

Keller, K. L. (1998). Strategic Brand Management: Building, Measuring and Managing Brand Equity. New Jersey, Prentice Hall.

Kent, T. (2007). "Creative space: design and the retail environment." International Journal of Retail and Distribution Management 35(5): 734-745.

Kent, T. (2003). "2D23D: Management and design perspectives on retail branding." International Journal of Retail \& Distribution Management 31(3): 131-142.

Keynote (2007). Market Report: Own Brands, Datamonitor. 
Keynote (2006). Market Review: Clothing and Footwear Industry, Datamonitor.

King, S. (1991). "Brand building in the 90's." Journal of Marketing Management 7(1): 50-56.

King, S. (1973). Developing New Brands. Bath, Pitman Publishing.

Knox, S. and D. Bickerton (2003). "The six conventions of corporate branding." European Journal of Marketing 37(7/8): 998-1016.

Knox, S., S. Malkan, et al. (2000). Building the unique organisational value proposition. The Expressive Organisation. M. Schultz, M. J. Hatch and M. H. Larsen. Oxford, Oxford University Press.

Kotler, P. and K. L. Keller (2006). Marketing Management. New Jersey, Pearson Education.

Kotler, P., G. Armstrong, et al. (1996). Principles of Marketing: The European Edition. Hemel Hempstead, Prentice Hall.

Kotler, P. (1984). Marketing Management: Analysis, Planning and Control. Englewood Cliffs, New Jersey, Prentice-Hall.

Martensen, R. (2007). "Corporate brand image, satisfaction and store loyalty." International Journal of Retail and Distribution Management 35(8): 544-555.

Martineau, P. (1958). "The Personality of the Retail Store." Harvard Business Review 36(1): 47-55.

McGoldrick, P. (2002). Retail Marketing. London, McGraw Hill.

Meeghan, T. (1995). "The role of advertising in brand image development." Journal of Product and Brand Management 4(4): 23-34.

Mintel (2007). Clothing Retailing - UK - Issues in the Market. London, Mintel Research.

Mintel (1998). Clothing Retail Review. Mintel Research. London.

Mitchell, A. (1999). "Out of the shadows." Journal of Marketing Management 15(1-3): 2542.

Moore, C. (1995). "From rags to riches-creating and benefiting from the fashion own-brand." International Journal of Retail and Distribution Management 23(9): 19-27.

Moore, C. and L. Shearer (1998). "Competitive Asset or Unnecessary Expense? the Role of the Designer within UK Fashion Retailing." Journal of Fashion Marketing and Management 2(3): 217-229.

Moore, C. and G. Birtwistle (2004). "The Burberry business: creating an international luxury fashion brand." International journal of Retail and Distribution Management 38(8): 412-422. 
Moore, C. and G. Birtwistle (2005). "The nature of parenting advantage in luxury fashion retailing - the case of Gucci group NV." International Journal of Retail \& Distribution Management 33(4): 256-270.

Moore, C. M. (2000). The Internationalisation of Foreign Fashion Retailers into the UK Market-Identifying the motives, methods and Operational Challenges, unpublished $\mathrm{PhD}$, Stirling University.

Olins, W. (2000). How brands are taking over the corporation. The Expressive Organisation. M. Schultz, J. M. Hatch and M. H. Larsen. Oxford, Oxford University Press: 51-65.

Omar, O. (1999). Retail Marketing. London, Financial Times Management.

Park, C., W. Jaworski, et al. (1986). "Strategic brand concept-image management." Journal of Marketing 50(October): 135-145.

Papasolomou, I. and D. Vrontis (2006). "Building corporate branding through internal marketing: the case of the UK retail bank industry." Journal of Product and Brand Management 15(1): 37-47.

Porter, S. S. and C. Claycomb (1997). "The influence of brand recognition on retail store image." Journal of Product and Brand management 6(6): 373-387.

Plummer, J. T. (1985). "How personality makes a difference." Journal of Advertising Research 24(6): 27-30.

Richardson, P., A. K. Jain, et al. (1996). "The influence of store aesthetics on evaluation of private label brands." Journal of Product and Brand management 5(1): 19-28.

Rubenstein, H. (2002). "Branding on the internet-moving from a communications to a relationship approach to branding." Interactive Marketing 4(1): 33-40.

Salzer-Morling, M. and 1. Strannegard (2004). "Silence of the brands." European Journal of Marketing 38(1/2).

Sheth, J. N., B. Mittal, et al. (1999). Customer Behaviour, Consumer Behaviour and Beyond. USA, Dryden Press.

Sheinin, D. A. and J. Wagner (2003). "Pricing store brands across categories and retailers." Journal of Product and Brand Management 12(4): 201-219.

Staveley, N. (1987). "Advertising, marketing and brands." Admap 23: 31-35.

Stern, B. (2006). "What does brand mean? Historical-analysis method and construct definition." Journal of the Academy of Marketing Science 34(2): 216-223.

Sudhir, K. and D. Talukdar (2004). "Does store brand patronage improve store patronage?" Review of Industrial Organisation 24: 143-160. 
Tungate, M. (2005) Fashion Brands: Branding Style from Armani to Zara, London, Kogan Page, UK

Urde, M. (2003). "Core value based corporate brand building." European Journal of Marketing 37(7/8): 1017-1040.

Vahie, A. and A. Paswan (2006). "Private label brand image: its relationship with store image and national brand." International Journal of Retail and Distribution Management 34(1): 6784.

Veloutsou, C., E. Gioulistanis, et al. (2004). "Own labels choice and perceived characteristics in greece and Scotland: factors influencing the willingness to buy." Journal of Product and Brand Management 13(4): 228-241.

Verdict (2007). Market View: UK Womenswear Retailing, Datamonitor.

Watkins, T. (1986). The Economics of the Brand. Maidenhead, McGraw Hill Book Company UK.

Wells, L. E., H. Farley, et al. (2007). "The importance of packaging design for own label food brands." International Journal of Retail and Distribution Management 35(9): 677-690.

Woodard, G., N. Cassill, et al. (1994). "The Relationship Between Psychological Climate and Work Motivation in a Retail Environment." The International Review of Retail, Distribution and Consumer Resarch 4(3): 297-314.

www.retailknowledgebank.net (2004). "Retail Week Top 500." Retrieved 10 ${ }^{\text {th }}$ January 2005. 